\title{
SIZE DISTRIBUTION OF TRACE ORGANIC SPECIES EMITTED FROM LIGHT-DUTY GASOLINE VEHICLES
}

\author{
Sarah G. Riddle ${ }^{1}$, Michael A. Robert ${ }^{2}$, Chris A. Jakober ${ }^{3}$, Michael P. Hannigan ${ }^{4}$, and \\ Michael J. Kleeman ${ }^{2} *$ \\ ${ }^{1}$ Department of Chemistry. University of California, Davis. 1 Shields Avenue, Davis CA \\ 95616. ${ }^{2}$ Department of Civil and Environmental Engineering, University of California, \\ Davis. 1 Shields Avenue, Davis CA 95616. ${ }^{3}$ Agriculture and Environmental Chemistry \\ Graduate Group, University of California, Davis. 1 Shields Avenue, Davis CA 95616. \\ ${ }^{4}$ Department of Mechanical Engineering, University of Colorado, Boulder CO.
}

*Corresponding author contact information: Department of Civil and Environmental Engineering, University of California, Davis, One Shields Avenue, Davis, CA 95616: e-mail: mjkleeman@ucdavis.edu: telephone: (530) 752-8386: fax: (530) 752-7872

\section{Supplementary Information}

\section{Details of the Sample Analysis for Organic Compounds}

Separation of the analytes is performed on an Agilent J\&W DB-XLBMSD capillary GC column ( $30 \mathrm{~m}$ x $0.25 \mathrm{~mm}$ i.d. $\times 0.25 \mu \mathrm{m}$ film thickness). The stationary phase for this particular column consists of a 5\% phenyl/95\% methyl substituted polysiloxane. The organic chemical speciation data collected for this project was obtained on a Varian 3400 gas chromatograph (GC) coupled with a Varian 2000 ion-trap mass spectrometer (ITMS). Samples volumes of $20 \mu \mathrm{L}$ are introduced into the injection port containing a liner with an approximately $1 / 8$ " plug of glass wool. The injection port is initially at a temperature of $35^{\circ} \mathrm{C}$, and is held for 5 minutes before the injection port temperature is ramped to $300{ }^{\circ} \mathrm{C}$ at a rate of $100{ }^{\circ} \mathrm{C} \mathrm{min}{ }^{-1}$. The introduction of samples in this manner allows us to use larger injection volumes than would be possible with a hot injector, which becomes limited by the solvent expansion volume in relation to the volume of the injection port liner. The GC column oven is held at an initial temperature of $35{ }^{\circ} \mathrm{C}$ for the first five minutes of the analysis. After five minutes the column oven is ramped to $330{ }^{\circ} \mathrm{C}$ at a rate of $5{ }^{\circ} \mathrm{C} \mathrm{min}^{-1}$. The column is held at this temperature for ten minutes, which leads to a total analysis time of 74 minutes per injection.

Operating parameters of the GC_ITMS are those recommended by the manufacturer with slight modification. The instrument was operated in electron impact (EI) ionization mass spectrometry/selected ion monitoring (SIM) mode. Operating conditions of the mass spectrometer are as follows: The ion trap oven, manifold and transfer line are held at 250,80 and $270{ }^{\circ} \mathrm{C}$ respectively. EI analyses are performed with an emission current of $10 \mu \mathrm{A}$, a target ion count of 2000 and a maximum ionization time of $25000 \mu \mathrm{sec}$. PAHs were measured by monitoring for the parent ion masses. Hopanes and steranes were monitored by scanning for their predominant fragment ions, $\mathrm{m} / \mathrm{z}=191$ 
and $\mathrm{m} / \mathrm{z}=217 / 218$ respectively. Chemical species were identified by a match in the relative retention time and a comparison of the analyte mass spectra to that of an authentic standard. When no authentic standard was available, analytes were identified by their mass spectrum and comparison of relative retention times and mass spectra to those in the literature (1). Limits of detection and limits of quantification are given in Table S2.

\section{Vehicle Test Matrix}

Table S1 summarizes the vehicle test matrix used for each light duty gasoline vehicle sample. Exhaust particles from multiple vehicles were composited during each test to provide an appropriate average and to obtain sufficient material for chemical analysis. Lower-emitting vehicle classes were driven through multiple cycles to obtain sufficient material for analysis. Vehicles were stored between cycles to obtain proper cold-start temperatures. Further details of the vehicle test matrix are discussed by Robert et al. (2).

\section{Quality Assurance}

Figure S1 shows the agreement between collocated MOUDI and RAAS measurements for 28 organic compounds of interest in the present study. Panels (a-n) illustrate agreement for hopanes and steranes that are useful tracers for motor oil. Panels (o-bb) illustrate agreement for non-volatile polycyclic aromatic hydrocarbons (PAHs). The error bars in Figure S1 reflect the analytical uncertainty of the GC-MS analysis.

In Figure S1, the solid line shown in each panel is a linear regression analysis between the MOUDI and sampling flow rate adjusted RAAS measurements for each organic compound. The dashed line is the 1:1 line. The regression slopes and correlation coefficients for each organic compound measured by MOUDI vs. RAAS filter sampler are given in Table S3. The disagreement between the MOUDI and filter-based samples may result from differences in flow rate between the two instruments, differences in loss rates within the sampler itself, and differences in analytical uncertainty for some of the analytes. The lack of a single relationship between MOUDI and filter-based measurements for all analytes suggests that all three factors may play a role.

Consistency between MOUDI and filter measurements is a necessary check to build confidence in the accuracy of the size distribution measurements. Most PAH species identified in this study behave consistently when collected with MOUDI and filter samplers. Five of the PAHs identified (compounds o, p, t, x, and y) exhibit less consistent behavior than the other PAHs quantified in this study; while the exact cause of the discrepancies for these compounds is unknown it may be due in part to the low concentrations that are near the limit of detection for the method used. Hopanes $17 \alpha(\mathrm{H})$ $21 \beta(\mathrm{H})$-29-norhopane (Figure S1 c) and $17 \alpha(\mathrm{H})-21 \beta(\mathrm{H})$-hopane (Figure S1 e) appear to exhibit the most consistent behavior between MOUDI and filter measurements as demonstrated by correlation slopes $=0.7526-0.9202$ and correlation coefficients $\mathrm{R}^{2}=$ 
0.9773- 0.9589, and these compounds are also observed in most samples. Hopanes 22R$17 \alpha(\mathrm{H})-21 \beta(\mathrm{H})-30$-homohopane (panel g) and 22S-17 $\alpha(\mathrm{H})-21 \beta(\mathrm{H})$-30-bishomohopane (panel h) also exhibit strong agreement between filter and MOUDI measurements but were not observed in all vehicle classes tested thus are not a good candidate for a sizeresolved motor vehicle particulate matter tracer. Other observed hopanes show reasonable agreement between the two measurements with slopes ranging from 0.5725 to 0.8912. Steranes $\alpha \beta \beta$-20R-stigmastane (panel $\mathrm{m}$ ) and $\alpha \beta \beta$-20S-stigmastane (panel $\mathrm{n}$ ) exhibit the most consistent behavior between MOUDI and filter measurements with correlation slopes $=0.8057-1.281$ and correlation coefficients $\mathrm{R}^{2}=0.8353-0.9402$. Four other steranes measured (panels $\mathrm{j}$, k, and $\mathrm{l}$ ) do not show such a strong agreement between sampling techniques with slopes of $0.4725,0.3598$, and 0.6537 and correlation coefficients less than 0.9. Lubricating oil tracers, $17 \alpha(\mathrm{H})-21 \beta(\mathrm{H})$-29-norhopane (Figure $\mathrm{S} 1 \mathrm{c}$ ), $17 \alpha(\mathrm{H})-21 \beta(\mathrm{H})$-hopane (Figure $\mathrm{S} 1 \mathrm{e}$ ), $\alpha \beta \beta$-20R-stigmastane (panel $\mathrm{m}$ ) and $\alpha \beta \beta$ 20S-stigmastane (panel $n$ ) appear to have the greatest promise as size-resolved tracers for vehicular particulate matter.

\section{Emission Factors}

Emission factors for all vehicles types and driving cycles are given in Table S4 for the PM 1.8 size fraction. Large differences in emission rates are seen for each motor vehicle class examined on the FTP cycle. Hopanes $17 \alpha(\mathrm{H})-21 \beta(\mathrm{H})-29$-norhopane and $17 \alpha(\mathrm{H})-21 \beta(\mathrm{H})$-hopane are emitted at a much higher rate from the SMOKER vehicles. The next highest tracer emission rates are observed from the OXY-CAT vehicles followed by the NON-CAT and HONDA TWC samples which have similar emission rates. Hopane emission rates are four to five times higher for the TWC LDT/SUV's than for the TWC cars. The lowest overall lubricating oil tracer emission rates were seen in the LEV sample which is two to three times less than those of the TWC vehicles. As expected, similar trends are also seen for steranes $\alpha \beta \beta$-20R-stigmastane and $\alpha \beta \beta-20 \mathrm{~S}$ stigmastane although they were not identified in every sample. PAHs emission rates are also much higher for the SMOKER vehicles than any others examined in this study as much as ten times higher than the next highest emitter of PAHs the NON-CAT vehicles. The OXY-CAT vehicles and the HONDA FTP vehicle have very comparable emission rates for all PAHs observed in both samples. LEV vehicles had the lowest PAH emission rates along with the TWC LDT/SUV vehicles. Emission rates for the TWC vehicle, while much lower than the OXY-CAT and NON-CAT vehicles are two to ten times higher than the LEV vehicles. It is interesting to note that the high emission rates of a few vehicle types could completely obscure the contributions from other vehicle types.

Comparisons of emission rates can also be made for the TWC vehicles driven on the FTP cycle versus the UC cycle. Emission rates for the hopanes are two to three times higher for vehicles driven on the UC cycle. No difference is seen between the PAHs for TWC vehicles driven on either cycle indicating that more lubricating oil is burned when a vehicle is operated on the UC cycle. Comparisons for the TWC LDT/SUV vehicles don't give similar results. For all compounds studied the FTP cycle had the lowest emission rates followed by the UC cycle and then the CC cycle. $17 \alpha(\mathrm{H})-21 \beta(\mathrm{H})-29$-norhopane, $17 \alpha(\mathrm{H})-21 \beta(\mathrm{H})$-hopane, $\alpha \beta \beta$-20R-stigmastane, and $\alpha \beta \beta$-20S-stigmastane are emitted at a 
two to three times higher rate when the vehicle is operated on the $\mathrm{CC}$ cycle than the UC cycle.

\section{Source Profiles}

Tables S5 and S6 show the concentrations of organic compounds relative to total organic mass $\left(\mu \mathrm{g} \mathrm{g}^{-1}\right)$ emitted by TWC vehicles operated under different driving cycles. PM0.1 hopanes and steranes emitted from the TWC PCs operated using the UC driving cycle failed quality control checks and are not reported. Table S5 shows that the relative concentration of hopanes and steranes in the PM1.8 size fraction was significantly enhanced during the UC driving cycle compared to the FTP cycle for TWC PCs. In contrast, Table S6 illustrates that the relative concentrations of hopanes and steranes are not enhanced in the PM1.8 emitted from TWC LDT/SUVs under the more strenuous UC and CC driving cycles compared to the FTP cycle. The different behavior may be caused by the use of "cold-starts" for the tests summarized in Table S5 and "warm-starts" for the tests summarized in Table S6.

Table S6 shows that the relative concentration of most hopanes and steranes in the PM0.1 size fraction decrease slightly under the more strenuous UC and CC driving cycles relative to the FTP. Figure 2 (g-i) illustrated that hopanes and steranes shift to smaller sizes under the heavier load conditions. The relative concentration of hopanes and steranes decreased under heavier load conditions because an even larger increase in organic matter occurred in the PM0.1 size fraction under the UC and CC driving cycles. Overall, the trends illustrated by variations in vehicle load conditions shown in Tables S5 and S6 reflect the fact that the PM1.8 concentration of organic matter decreases under heavier load conditions while the PM0.1 concentration of organic matter increases. A full discussion of organic matter emissions during the current tests is provided by Robert et al.(2).

The lower portions of Tables S5 and S6 illustrate the effect of driving cycles on the relative concentrations of PAHs emitted from TWC vehicles in the PM0.1 and PM1.8 size fractions. Table 3 in the main text shows that the relative concentration of PAHs in the PM0.1 size fraction decreases by an order of magnitude under the UC driving cycle vs. the FTP cycle. Figures $3(b, f)$ in the main text illustrate that the size distribution of PAHs did not shift substantially between the FTP and UC driving cycle tests. The change in relative PAH concentrations are once again caused by an increase in the organic matter concentration in the PM0.1 size fraction during the UC test. Table S6 shows that similar trends cannot be detected during the TWC tests involving "warmstarts" because many of the PAHs were below the method detection limit due to light sample loadings. A regression analysis of the size distributions illustrated in the current study suggest that fuel and oil make separate contributions to the emitted particles, with hopanes and steranes acting as tracers for oil and heavy PAHs acting as tracers for fuel (3). The PAH trends illustrated in Table 3 suggest that the more strenuous UC cycle results in higher oil emissions (slightly weighted towards the ultrafine size range) providing more $\mathrm{OC}$ that dilutes the apparent relative concentration of PAHs. 


\section{References}

(1) Philip, R. P. Fossil Fuel Biomarkers Applications and Spectra; Elsevier Science Publishers: New York, 1985.

(2) Robert, M. A.; Jakober, C. A.; Kleeman, M. J. Size and composition distribution of particulate matter 1. Light-duty gasoline vehicles. J. Air Waste Manage. 2007, submitted for publication.

(3) Kleeman, M. J.; Riddle, S.; Robert, M. A.; Jakober, C. A. Lubricating Oil and Fuel Contributions to Particulate Matter Emissions From Light Duty Gasoline and Heavy Duty Diesel Vehicles. Environ. Sci. Technol. 2007, submitted for publication. 


\begin{tabular}{|l|l|l|l|l|l|l|}
\hline $\begin{array}{l}\text { Sample } \\
\text { ID }\end{array}$ & $\begin{array}{l}\text { Vehicle Class } \\
\text { (number of vehicles) }\end{array}$ & $\begin{array}{l}\text { Average Year } / \\
\text { Odometer Reading } \\
\text { (miles) }\end{array}$ & $\begin{array}{l}\text { Drivng cycle } \\
\text { (number } \\
\text { of repeats) }\end{array}$ & $\begin{array}{l}\text { Total } \\
\text { Miles }\end{array}$ & $\begin{array}{l}\text { Dilution } \\
\text { Factor }\end{array}$ & $\begin{array}{l}\text { PM1.8 } \\
\text { Emissions } \\
(\mu \mathrm{g} / \mathrm{km})\end{array}$ \\
\hline LDV-1 & LEV (10) & $2000 / 46,679$ & FTP $(4)$ & 443.6 & 127.3 & 370 \\
\hline LDV-2 & TWC - PC (7) & $1993 / 84,176$ & FTP $(2)$ & 133.1 & 125.7 & 910 \\
\hline LDV-3 & TWC - PC (7) & $1993 / 84,176$ & UC $(1)$ & 64.2 & 55.8 & 1323 \\
\hline LDV-5 & TWC - LDT/SUV (6) & $1992 / 91,531$ & UC (1) & 49.1 & 47.3 & 8327 \\
\hline LDV-6 & TWC - LDT/SUV (6) & $1992 / 91,531$ & CC (1) & 130.6 & 37.9 & 2547 \\
\hline LDV-7 & TWC - LDT/SUV (6) & $1992 / 91,531$ & FTP (1) & 37.6 & 66.9 & 842 \\
\hline LDV-8 & OCAT (3) & $1979 / 71,807^{*}$ & FTP $(1)$ & 33.3 & 392.5 & 15767 \\
\hline LDV-9 & NCAT (2) & $1959 / 75,728^{*}$ & FTP $(1)$ & 22.2 & 129.3 & 7926 \\
\hline LDV-10 & SMOKER (2) & $1981 / 113,186^{*}$ & FTP $(1)$ & 22.2 & 124.2 & 213354 \\
\hline
\end{tabular}

*mileage estimates may be inaccurate due to odometer rollover.

Table S1: Summary of vehicle test matrix. Results from test LDV-4 are not included in the current analysis. 


\begin{tabular}{|c|c|c|}
\hline \multicolumn{3}{|l|}{ Compound } \\
\hline Hopanes & $\begin{array}{c}\text { LOQ } \\
(\mathrm{pg} / \mu \mathrm{L})^{\mathrm{a}}\end{array}$ & $\begin{array}{c}\text { LOD } \\
(\mathrm{pg} / \mu \mathrm{L})^{\mathrm{b}}\end{array}$ \\
\hline $18 \alpha(\mathrm{H})-21 \beta(\mathrm{H})-22,29,30$-trisnorhpane ${ }^{\mathrm{c}}$ & 6.2 & 1.8 \\
\hline $17 \alpha(\mathrm{H})-21 \beta(\mathrm{H})-22,29,30$-trisnorhpane ${ }^{\mathrm{c}}$ & 6.2 & 1.8 \\
\hline $17 \alpha(\mathrm{H})-21 \beta(\mathrm{H})-29-$ norhpane & 6.2 & 1.8 \\
\hline $18 \alpha(\mathrm{H})$-29-norneohopane ${ }^{\mathrm{c}}$ & 4.8 & 1.4 \\
\hline $17 \alpha(\mathrm{H})-21 \beta(\mathrm{H})$-hopane & 4.8 & 1.4 \\
\hline $22 \mathrm{~S}-17 \alpha(\mathrm{H})-21 \beta(\mathrm{H})-30$-homohopane ${ }^{\mathrm{c}}$ & 4.8 & 1.4 \\
\hline $22 \mathrm{R}-17 \alpha(\mathrm{H})-21 \beta(\mathrm{H})-30$-homohopane ${ }^{\mathrm{c}}$ & 4.8 & 1.4 \\
\hline $22 \mathrm{~S}-17 \alpha(\mathrm{H})-21 \beta(\mathrm{H})-30$-bishomohopane ${ }^{\mathrm{c}}$ & 4.8 & 1.4 \\
\hline $22 \mathrm{R}-17 \alpha(\mathrm{H})-21 \beta(\mathrm{H})-30$-bishomohopane ${ }^{\mathrm{c}}$ & 4.8 & 1.4 \\
\hline \multicolumn{3}{|l|}{ Steranes } \\
\hline $20 \mathrm{R}, 13 \beta(\mathrm{H})-17 \alpha(\mathrm{H})$-diacholestane $^{\mathrm{c}}$ & 9.7 & 2.9 \\
\hline $20 \mathrm{~S}, 13 \beta(\mathrm{H})-17 \alpha(\mathrm{H})$-diacholestane ${ }^{\mathrm{c}}$ & 9.7 & 2.9 \\
\hline$\alpha \alpha \alpha$-20S-stigmastane ${ }^{c}$ & 5.3 & 1.6 \\
\hline$\alpha \beta \beta$-20R-stigmastane & 5.3 & 1.6 \\
\hline$\alpha \beta \beta$-20S-stigmastane ${ }^{\mathrm{c}}$ & 5.3 & 1.6 \\
\hline \multicolumn{3}{|l|}{ PAHs } \\
\hline benzo[b]fluoranthene & 0.46 & 0.14 \\
\hline benzo[k]fluoranthene & 0.44 & 0.12 \\
\hline benzo[e]pyrene & 1.2 & 0.36 \\
\hline benzo[a]pyrene & 0.26 & 0.08 \\
\hline perylene & 0.47 & 0.14 \\
\hline indeno[1,2,3-cd]pyrene & 0.62 & 0.18 \\
\hline benzo[ghi]perylene & 0.76 & 0.22 \\
\hline indeno[ $[1,2,3-\mathrm{cd}]$ fluoranthene $^{\mathrm{c}}$ & 0.62 & 0.18 \\
\hline dibenzo[def,mno]chrysene $^{\mathrm{c}}$ & 0.76 & 0.22 \\
\hline dibenzo[a,c $+\mathrm{a}, \mathrm{h}]$ anthracene & 1.4 & 0.42 \\
\hline benzo[b]chrysene ${ }^{\mathrm{c}}$ & 1.4 & 0.42 \\
\hline coronene & 2.2 & 0.66 \\
\hline MW 302 isomers group $1^{c}$ & 2.4 & 0.73 \\
\hline MW 302 isomers group $2^{c}$ & 2.4 & 0.73 \\
\hline \multicolumn{3}{|c|}{$\begin{array}{l}{ }^{a} \text { Limit of quantification determined using a signal:noise ratio of } 10: 1,{ }^{b} \\
\text { Limit of detection determined using a signal:noise ratio of } 3: 1 \text {, }{ }^{\text {no pore }} \\
\text { standard available LOQ and LOD estimated using a standard compound } \\
\text { of the same class with the closest retention time }\end{array}$} \\
\hline
\end{tabular}

Table S2: Instrumental Limits of Quantification and Detection 


\begin{tabular}{|c|c|c|}
\hline Compound & & \\
\hline Hopanes & slope & $\mathbf{R}^{2}$ \\
\hline $18 \alpha(\mathrm{H})-21 \beta(\mathrm{H})-22,29,30$-trisnorhpane ${ }^{1}$ & 0.69 & 0.94 \\
\hline $17 \alpha(\mathrm{H})-21 \beta(\mathrm{H})-22,29,30$-trisnorhpane ${ }^{1}$ & 0.98 & 0.96 \\
\hline $17 \alpha(\mathrm{H})-21 \beta(\mathrm{H})-29$-norhpane & 0.92 & 0.98 \\
\hline $18 \alpha(\mathrm{H})-29$-norneohopane ${ }^{1}$ & 0.57 & 0.75 \\
\hline $17 \alpha(\mathrm{H})-21 \beta(\mathrm{H})$-hopane & 0.75 & 0.96 \\
\hline $22 \mathrm{~S}-17 \alpha(\mathrm{H})-21 \beta(\mathrm{H})-30$-homohopane ${ }^{1}$ & 0.89 & 0.77 \\
\hline $22 \mathrm{R}-17 \alpha(\mathrm{H})-21 \beta(\mathrm{H})-30$-homohopane ${ }^{1}$ & 0.98 & 0.98 \\
\hline $22 \mathrm{~S}-17 \alpha(\mathrm{H})-21 \beta(\mathrm{H})-30$-bishomohopane ${ }^{1}$ & 0.96 & 0.97 \\
\hline 22R-17 $\alpha(\mathrm{H})-21 \beta(\mathrm{H})-30$-bishomohopane ${ }^{1}$ & 0.60 & 0.69 \\
\hline \multicolumn{3}{|l|}{ Steranes } \\
\hline $20 \mathrm{R}, 13 \beta(\mathrm{H})-17 \alpha(\mathrm{H})$-diacholestane ${ }^{1}$ & 0.47 & 0.88 \\
\hline $20 \mathrm{~S}, 13 \beta(\mathrm{H})-17 \alpha(\mathrm{H})$-diacholestane ${ }^{1}$ & 0.368 & 0.59 \\
\hline$\alpha \alpha \alpha-20 S$-stigmastane ${ }^{1}$ & 0.65 & 0.85 \\
\hline$\alpha \beta \beta$-20R-stigmastane & 0.81 & 0.84 \\
\hline$\alpha \beta \beta$-20S-stigmastane ${ }^{1}$ & 1.3 & 0.94 \\
\hline \multicolumn{3}{|l|}{ PAHs } \\
\hline benzo[b]fluoranthene & 0.56 & 0.98 \\
\hline benzo[k]fluoranthene & 0.31 & 0.80 \\
\hline benzo[e]pyrene & 0.87 & 0.99 \\
\hline benzo[a]pyrene & 1.0 & 1.0 \\
\hline perylene & 1.0 & 0.98 \\
\hline indeno[1,2,3-cd]pyrene & 0.56 & 0.96 \\
\hline benzo[ghi]perylene & 0.66 & 1.0 \\
\hline indeno[1,2,3-cd]fluoranthene $^{1}$ & 0.83 & 0.99 \\
\hline dibenzo[def,mno]chrysene $^{I}$ & 0.89 & 0.99 \\
\hline dibenzo[a,c $+a, h]$ anthracene & 0.46 & 0.25 \\
\hline benzo[b]chrysene $^{1}$ & 0.53 & 0.99 \\
\hline coronene & 0.68 & 1.0 \\
\hline MW 302 isomers group $1^{1}$ & 0.71 & 0.97 \\
\hline MW 302 isomers group $2^{1}$ & 0.63 & 0.96 \\
\hline
\end{tabular}

Table S3: Linear regression statistics for MOUDI mass vs. collocated filter mass 


\begin{tabular}{|c|c|c|c|c|c|c|c|c|c|}
\hline Compound & LEV & TWC & TWC & $\begin{array}{l}\text { TWC } \\
\text { LDT/ } \\
\text { SUV }\end{array}$ & $\begin{array}{l}\text { TWC } \\
\text { LDT/ } \\
\text { SUV }\end{array}$ & $\begin{array}{l}\text { TWC } \\
\text { LDT/ } \\
\text { SUV }\end{array}$ & $\begin{array}{l}\text { OXY } \\
\text {-CAT }\end{array}$ & $\begin{array}{l}\text { NON } \\
\text {-CAT }\end{array}$ & SMOKER \\
\hline Hopanes & FTP & FTP & $\mathbf{U C}$ & $\mathbf{C C}$ & $\mathbf{U C}$ & FTP & FTP & FTP & FTP \\
\hline $\begin{array}{l}17 \alpha(\mathrm{H})-21 \beta(\mathrm{H})-22,29, \\
\text { 30-trisnorhpane }\end{array}$ & 0.02 & ND & ND & 0.57 & ND & 0.17 & ND & ND & 4.45 \\
\hline $\begin{array}{l}17 \alpha(\mathrm{H})-21 \beta(\mathrm{H})-29- \\
\text { norhpane }\end{array}$ & 0.02 & 0.06 & 0.48 & 1.30 & 0.43 & 0.26 & 1.46 & 0.78 & 14.04 \\
\hline $\begin{array}{l}17 \alpha(\mathrm{H})-21 \beta(\mathrm{H})- \\
\text { hopane }\end{array}$ & 0.02 & 0.04 & 0.75 & 1.43 & 0.63 & 0.26 & 1.73 & 0.70 & 10.27 \\
\hline $\begin{array}{l}\text { 22S-17 } \alpha(\mathrm{H})-21 \beta(\mathrm{H})- \\
\text { 30-homohopane }\end{array}$ & ND & ND & 0.28 & 0.51 & 0.27 & 0.09 & ND & ND & 3.12 \\
\hline $\begin{array}{l}22 \mathrm{R}-17 \alpha(\mathrm{H})-21 \beta(\mathrm{H})- \\
30 \text {-homohopane }^{1}\end{array}$ & ND & ND & 0.17 & 0.38 & 0.13 & 0.11 & ND & ND & 3.01 \\
\hline $\begin{array}{l}\text { 22S-17 } \alpha(\mathrm{H})-21 \beta(\mathrm{H})- \\
\text { 30-bishomohopane }\end{array}$ & ND & ND & 0.15 & 0.27 & 0.09 & 0.05 & ND & ND & 2.03 \\
\hline \multicolumn{10}{|l|}{ Steranes } \\
\hline$\alpha \beta \beta$-20R-stigmastane & 0.01 & ND & 0.19 & 0.54 & 0.21 & 0.11 & 0.27 & 0.63 & 5.02 \\
\hline$\alpha \beta \beta$-20S-stigmastane ${ }^{1}$ & ND & 0.02 & 0.11 & 0.25 & 0.08 & 0.05 & ND & 0.34 & 2.84 \\
\hline \multicolumn{10}{|l|}{ PAHs } \\
\hline benzo[e]pyrene & 0.03 & 0.13 & 0.15 & 0.87 & 0.11 & 0.02 & 1.07 & 3.05 & 19.23 \\
\hline benzo[a]pyrene & 0.03 & 0.14 & 0.12 & 0.53 & 0.07 & ND & 0.42 & 2.64 & 21.89 \\
\hline Perylene & 0.01 & 0.07 & 0.04 & 0.18 & 0.04 & ND & 0.31 & 0.52 & 4.66 \\
\hline benzo[ghi]perylene & 0.08 & 0.44 & 0.38 & 2.17 & 0.25 & 0.05 & 3.41 & 16.03 & 70.53 \\
\hline $\begin{array}{l}\text { indeno[1,2,3-cd] } \\
\text { fluoranthene }^{1}\end{array}$ & 0.02 & 0.11 & 0.10 & 0.22 & 0.07 & ND & 0.43 & 1.60 & 6.39 \\
\hline $\begin{array}{l}\text { dibenzo[def,mno] } \\
\text { chrysene }^{1}\end{array}$ & 0.01 & 0.04 & 0.04 & 0.11 & 0.02 & ND & ND & 0.72 & 8.29 \\
\hline Coronene & 0.04 & 0.45 & 0.21 & 1.16 & 0.25 & 0.02 & 2.13 & 16.42 & 42.15 \\
\hline MW 302 isomers $^{1}$ & 0.06 & 0.39 & 0.23 & 0.97 & 0.19 & ND & 1.02 & 3.37 & 11.37 \\
\hline
\end{tabular}

Table S4: PM 1.8 emission factors $(\mu \mathrm{g} / \mathrm{km})$. 


\begin{tabular}{|c|c|c|c|c|c|c|c|c|}
\hline \multirow{3}{*}{$\begin{array}{l}\text { Compound } \\
\text { Hopanes }\end{array}$} & \multicolumn{4}{|c|}{ PM 0.1 } & \multicolumn{4}{|c|}{ PM 1.8} \\
\hline & \multicolumn{2}{|c|}{ FTP } & \multicolumn{2}{|c|}{$\mathbf{U C}$} & \multicolumn{2}{|c|}{ FTP } & \multicolumn{2}{|c|}{$\mathbf{U C}$} \\
\hline & ratio & error & ratio & error & ratio & error & ratio & error \\
\hline $17 \alpha(\mathrm{H})-21 \beta(\mathrm{H})-29$-norhopane & 467 & 19 & ND & & 153 & 1 & 753 & 16 \\
\hline $17 \alpha(\mathrm{H})-21 \beta(\mathrm{H})$-hopane & 686 & 28 & ND & & 100 & 2 & 1177 & 25 \\
\hline \multicolumn{9}{|l|}{ Steranes } \\
\hline$\alpha \beta \beta$-20R-stigmastane & 244 & 10 & ND & & ND & & 295 & 4 \\
\hline$\alpha \beta \beta$-20S-stigmastane ${ }^{1}$ & 91 & 4 & ND & & 45 & 1 & 170 & 7 \\
\hline \multicolumn{9}{|l|}{ PAHs } \\
\hline benzo[e]pyrene & 69 & 7 & 19 & 0.6 & 300 & 4 & 243 & 6 \\
\hline benzo[a]pyrene & 142 & 7 & 24 & 2 & 346 & 4 & 188 & 6 \\
\hline perylene & 56 & 9 & 7 & 2 & 169 & 4 & 58 & 4 \\
\hline benzo[ghi]perylene & 785 & 34 & 111 & 2 & 1050 & 8 & 603 & 13 \\
\hline indeno[1,2,3-cd]fluoranthene ${ }^{1}$ & 201 & 9 & 28 & 0.5 & 265 & 2 & 160 & 4 \\
\hline dibenzo[def,mno]chrysene $^{1}$ & 100 & 12 & 18 & 2 & 104 & 4 & 67 & 4 \\
\hline coronene & 577 & 24 & 71 & 0.8 & 1077 & 7 & 325 & 7 \\
\hline MW 302 isomers ${ }^{1}$ & 368 & 15 & 45 & 0.6 & 457 & 4 & 185 & 4 \\
\hline
\end{tabular}

Table S5: PM 0.1 and PM 1.8 ratio of analyte mass to total organic carbon mass $\left(\mu \mathrm{g} \mathrm{g}^{-1}\right)$ for TWC-PC vehicles operated under FTP and UC driving cycles. 


\begin{tabular}{|c|c|c|c|c|c|c|c|c|c|c|c|c|}
\hline \multirow{3}{*}{\begin{tabular}{|l}
\multicolumn{1}{|c}{ Compound } \\
\\
Hopanes
\end{tabular}} & \multicolumn{6}{|c|}{ PM 0.1} & \multicolumn{6}{|c|}{ PM 1.8} \\
\hline & \multicolumn{2}{|c|}{ FTP } & \multicolumn{2}{|c|}{$\mathbf{U C}$} & \multicolumn{2}{|c|}{$\mathbf{C C}$} & \multicolumn{2}{|c|}{ FTP } & \multicolumn{2}{|c|}{$\mathbf{U C}$} & \multicolumn{2}{|c|}{$\mathrm{CC}$} \\
\hline & ratio & error & ratio & error & ratio & error & ratio & error & ratio & error & ratio & error \\
\hline $\begin{array}{l}17 \alpha(\mathrm{H})-21 \beta(\mathrm{H})-29- \\
\text { norhopane }\end{array}$ & 136 & 13 & 282 & 2 & 240 & 2 & 430 & 37 & 269 & 3 & 325 & 4 \\
\hline $17 \alpha(\mathrm{H})-21 \beta(\mathrm{H})$-hopane & 630 & 58 & 273 & 2 & 336 & 3 & 430 & 37 & 294 & 3 & 477 & 5 \\
\hline \multicolumn{13}{|l|}{ Steranes } \\
\hline$\alpha \beta \beta$-20R-stigmastane & 189 & 22 & 46 & 0.6 & 110 & 1 & 179 & 16 & 111 & 1 & 161 & 2 \\
\hline$\alpha \beta \beta$-20S-stigmastane ${ }^{1}$ & 78 & 17 & 51 & 0.6 & 46 & 0.5 & 79 & 8 & 52 & 0.6 & 62 & 0.7 \\
\hline \multicolumn{13}{|l|}{ PAHs } \\
\hline benzo[e]pyrene & 38 & 7 & 116 & 1 & 48 & 1 & 39 & 4 & 180 & 2 & 83 & 1 \\
\hline benzo[a]pyrene & ND & & 32 & 1 & 32 & 0.7 & ND & & 110 & 2 & 54 & 0.8 \\
\hline perylene & ND & & 21 & 0.7 & 18 & 1 & ND & & 37 & 0.6 & 28 & 0.8 \\
\hline benzo[ghi]perylene & 89 & 26 & 372 & 3 & 86 & 2 & 74 & 10 & 446 & 5 & 191 & 3 \\
\hline $\begin{array}{l}\text { indeno[1,2,3- } \\
\text { cd]fluoranthene }\end{array}$ & 17 & 6 & 60 & 0.4 & 20 & 0.5 & ND & & 45 & 0.5 & 49 & 0.6 \\
\hline dibenzo[def,mno]chrysene ${ }^{1}$ & ND & & ND & & 6 & 2 & ND & & 23 & 0.7 & 13 & 1 \\
\hline coronene & ND & & 242 & 2 & 101 & 1 & 33 & 3 & 239 & 3 & 185 & 2 \\
\hline MW 302 isomers ${ }^{1}$ & ND & & 72 & 0.5 & 33 & 0.5 & ND & & 100 & 1 & 69 & 1 \\
\hline
\end{tabular}

Table S6: PM 0.1 and PM 1.8 ratio of analyte mass to total organic carbon mass $\left(\mu \mathrm{g} \mathrm{g}^{-1}\right)$ for LDT/SUV vehicles operated under FTP, UC, and CC driving cycles. All tests were "warm-starts". FTP test only included the first two modes of the standard FTP cycle. 

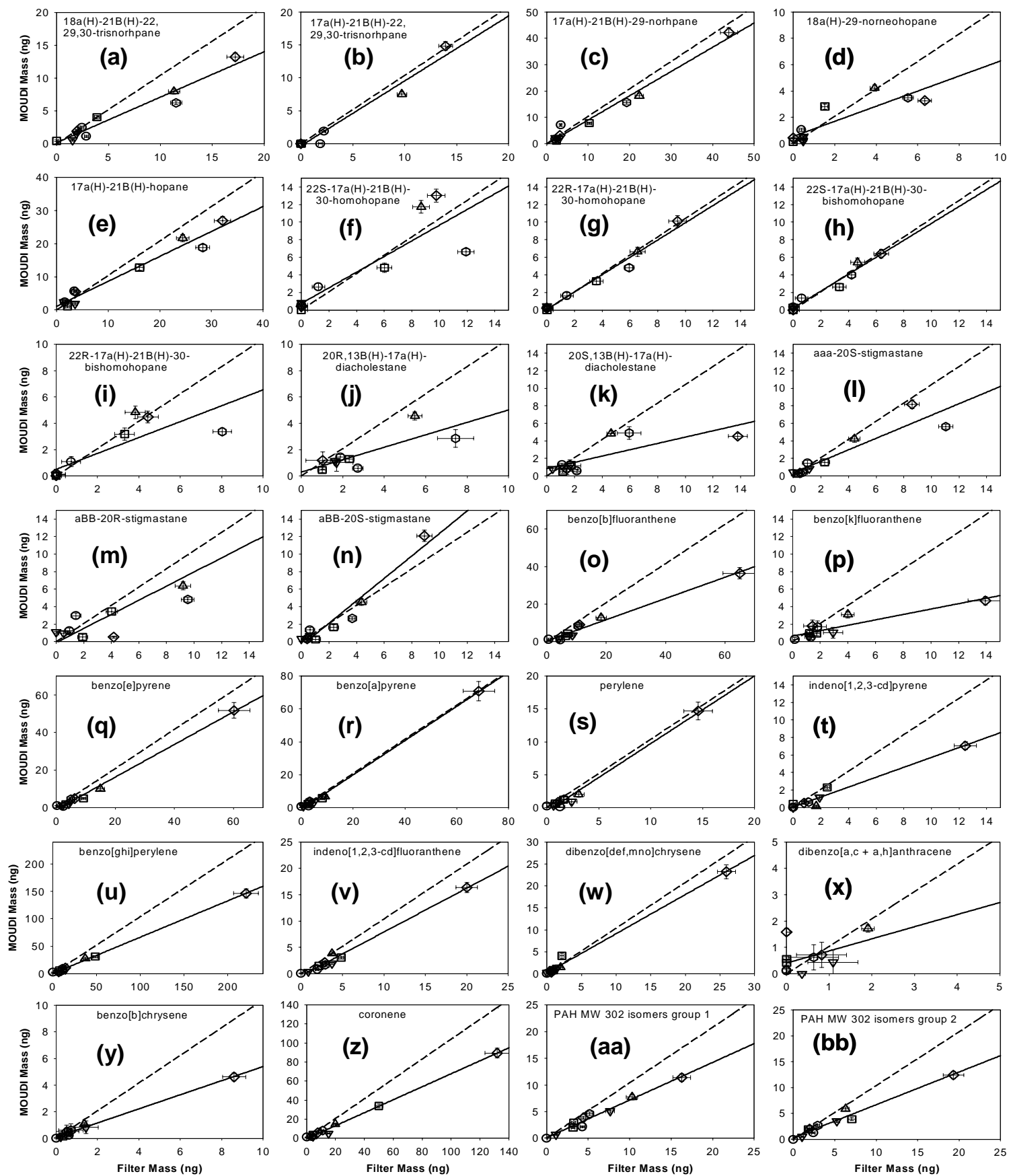

\section{O LEV FTP \\ ○ TWC LDT/SUC CC \\ () TWC FTP \\ $\nabla$ TWC UC \\ 8 TWC LDT/SUV FTP \\ $\nabla$ TWC HONDA \\ 8. OXY-CAT FTP \\ $\square$ TWC LDT/SUV UC A SMOKER FTP}

Figure S1: Comparison between the mass collected by the MOUDI sampler with the PM1.8 filter mass. All MOUDI values include the after-filter. Dashed line is 1:1; solid line is best-fit regression. 